Volume 2 Nomor 2, September 2020, Halaman 57 - 69.

\title{
MANAJEMEN STRATEGI INDUSTRI KECIL MENENGAH PABRIK KERUPUK SARI IKAN DESA PENGANJANG KECAMATAN SINDANG KABUPATEN INDRAMAYU
}

\author{
Meddy Nurpratama ${ }^{1)}$, Samsul Anwar ${ }^{2)}$ \\ ${ }^{1.2)}$ Prodi Manajemen, Universitas Wiralodra \\ Email: meddynurpratamafe@unwir.ac.id, samsulanwarfe@unwir.ac.id.
}

\begin{abstract}
Abstrak
Industri pangan sering dipandang sebelah mata, beberapa makanan tradisional yang dikerjakan oleh pengusaha-pengusaha kecil banyak yang hanya sekedar mengemas dan melupakan fungsi-fungsi dari sebuah kemasan dalam persaingan pasar saat ini. Pada penelitian ini bermaksud untuk mengkaji dan mempelajari strategi industri kecil menengah Pabrik Kerupuk Sari Ikan Desa Penganjang Kecamatan Sindang Kabupaten Indramayu. Pengabdian ini menggunakan pendekatan deskriptif. Pengambilan data menggunakan observasi dan wawancara. Subyek pengabdian ini adalah sebuah Industri Kecil Menengah (IKM) yang ada di Desa Penganjang Kecamatan Sindang Kabupaten Indramayu yaitu Pabrik Kerupuk Sari Ikan Bapak Iing Imanudin. Pengumpulan data dilakukan dengan obervasi dan wawancara kepada pemilik industri kecil menengah untuk menjawab tujuan dari penelitian ini. Hasil penelitian berupa data - data yang diperlukan untuk meningkatkan kegiatan memasarkan poduk ke luar indramayu, inovasi produk dengan menambah varian rasa, memberikan masukan dalam proses penjemuran, menyusun struktur organisasi, jadwal jam kerja terlaksana, job description, visi misi perusahaan dan membuat laporan keuangan. Melalui strategi ini diharapkan semakin maju dan berkembang serta bisa bersaing dengan perusahan yang lebih modern.
\end{abstract}

Kata Kunci: Manajemen Strategi, Observasi, Industri Kecil Menengah

Abtract

The food of industry is often underestimated, some of the traditional foods are done by small entrepreneurs, many of which are just packaging and forgetting the functions of a package in today's market competition. This research intends to study and study the strategies of the small and medium-sized industry of the Penganjang Sari Ikan Kerupuk Factory, Sindang District, Indramayu Regency. This service uses a descriptive approach. Collecting data using observation and interviews. The subject of this service is a Small and Medium Industry (IKM) in Penganjang Village, Sindang District, Indramayu Regency, namely Mr. Iing Imanudin, Fish Sari Crackers Factory. Data collection was carried out by observation and interviews with small and medium industry owners to answer the objectives of this study. The results of the research are in the form of data needed to improve product marketing activities outside Indramayu, product innovation by adding flavor variants, 
providing input in the drying process, compiling an organizational structure, implementing working hours, job descriptions, company vision and mission and making financial reports. Through this strategy, it is hoped that it will be more advanced and develop and can compete with more modern companies. Keywords: Strategy Management, observation, Small and Medium Industries

\section{A. Pendahuluan}

Industri pangan di Indonesia, sering dipandang sebelah mata. Beberapa makanan tradisional yang dikerjakan oleh pengusaha-pengusaha kecil banyak yang hanya sekedar mengemas dan melupakan fungsi-fungsi dari sebuah kemasan dalam persaingan pasar saat ini. Padahal di era global ini, pesaingan dagang semakin ketat dengan masuknya produk-produk asing dengan kemasan yang menarik dengan harga bersaing, membuat produk Indonesia kalah bersaing dalam mendapatakan kepercayaan dari konsumen akan kualitas produk.

Kerupuk adalah salah satu makanan khas Indonesia yang sangat diminati banyak orang baik dari golongan menengah kebawah hingga menengah ke atas, mulai dari anak kecil hingga orang dewasa. Kerupuk dibuat dari bahan-bahan sederhana tapi membuat setiap makanan terasa lengkap. Sebenarnya kerupuk adalah makanan ringan, tapi teryata peluang berbisnis kerupuk sangat besar. Tidak heran sampai saat ini bisnis kerupuk masih banyak diproduksi dan peminatnya semakin banyak.

Perusahaan milik pak Iing Imanudin berdiri sejak tahun 1993 berada di desa Anjun Paoman Indramayu, lalu pindah pada tahun 1994 di desa Penganjang Kecamatan Sindang Kabupaten Indramayu. Bapak ling merintis pabrik kerupuk sari ikan, yang pada awalnya beliau bekerja dipabrik kerupuk orang lain selama 7 tahun, selama bekerja pabrik tersebut Bapak ling mengambil ilmu dari proses pembuatan kerupuk tersebut sehingga mempunyai motivasi untuk membuka usaha pabrik kerupuk sendiri. Pabrik kerupuk ini membutuhkan modal awal sekitar Rp. 5.000.000,-. Kerupuk buatan Pak ling ini berbeda dengan yang biasa kita makan, dari bentuknya dapat dibedakan, volumenya lebih kecil, rasanya pun lebih gurih dan lebih renyah. Kerupuk ini dinamakan "KERUPUK SARI IKAN" di karenakan ada campuran rasa ikannya. Selanjutnya dilakukan wawancara untuk analisis studi. 


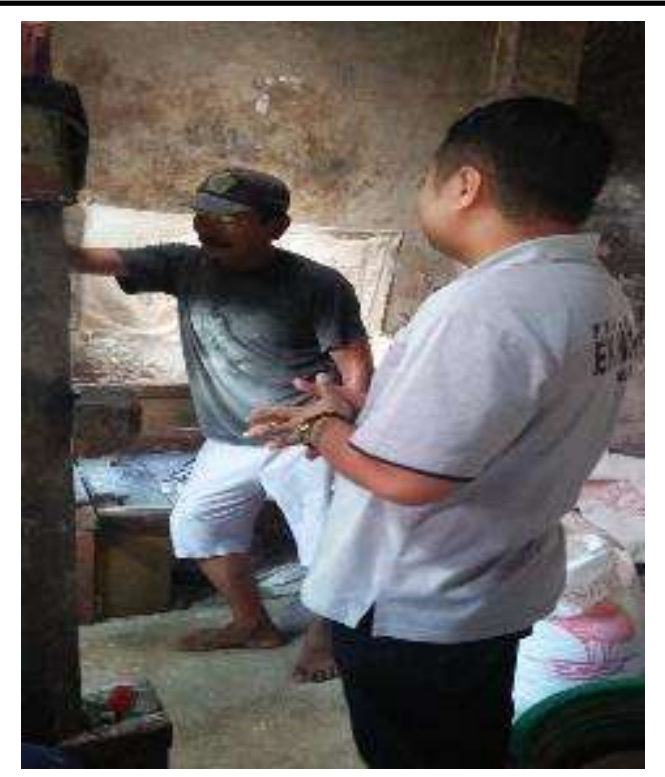

Gambar 1. Wawancara investigasi awal

Pada gambar 1 adalah unjungan awal observasi, mencatat dan menggali informasi kepada pemilik IKM dari mulai permasalahan penjualan, sumber daya manusia, keuangan, dan produksi yang ada pada IKM kerupuk sari ikan. Setelah dilakukan wawancara kepada Pak Iing, permasalahan yang dihadapi oleh industri kecil menengah ini adalah (1) pembukuan keuangan perusahaan yang baik, (2) Job Description, (3) Struktur organisasi, (4) Jadwal jam kerja, (5) Tidak ada Visi Misi perusahaan, dan kurangnya pemasaraan. Tim pengabdian memilih "KERUPUK SARI IKAN" karena industry ini adalah salah satu industri kecil menengah yang cukup berkembang di penganjang. Selain itu salah satu tempat insudtri yang bersedia untuk bekerjasama dengan tim pengabdian ini adalah "KERUPUK SARI IKAN".

Berdasarkan uraian tersebut maka pada penulisan ini ingin mengkaji mengenai manajemen strategi industri kecil menengah pabrik Kerupuk Sari Ikan Desa Penganjang Kecamatan Sindang Kabupaten Indramayu.

\section{B. Metode}

Penelitian ini menggunakan jenis penelitian deskriptif. Pada penelitian ini bermaksud untuk mengkaji dan mempelajari manajemen strategi industri kecil menengah Pabrik Kerupuk Sari Ikan Desa Penganjang Kecamatan Sindang Kabupaten Indramayu. Subyeknya adalah sebuah Industri Kecil Menengah (IKM) 
yang ada di Desa Penganjang Kecamatan Sindang Kabupaten Indramayu yaitu Pabrik Kerupuk Sari Ikan Bapak Iing Imanudin. Pengumpulan data dilakukan dengan obervasi dan wawancara kepada pemilik industri kecil menengah untuk menjawab tujuan dari penelitian ini

\section{Hasil dan Pembahasan}

1. Hasil Pengabdian

Pengabdian dilakukan oelh tim selama 3 minggu. Berikut akan ditampilkan gambar pengamatan tim ke tempat pengabdian.

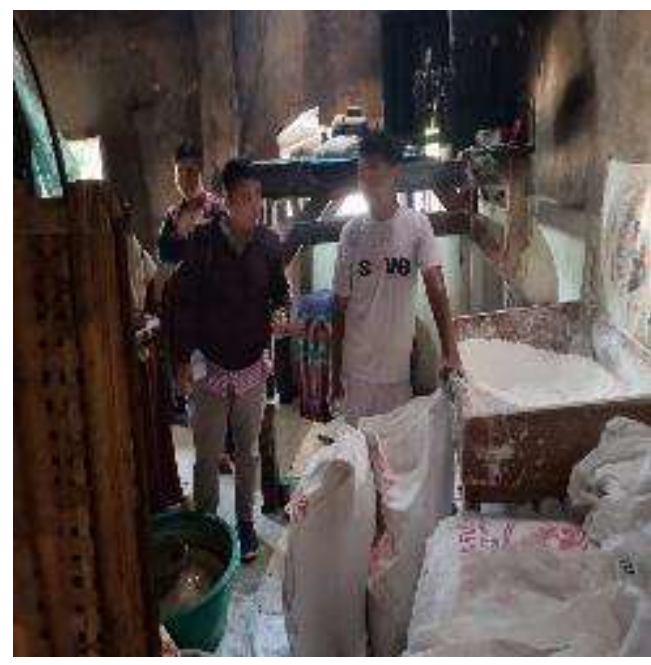

Gambar 2. Kunjungan Tim Pengabdian

Pada gambar 2 merupakan kunjungan Minggu ke 3 setelah mencatat hasil dari informasi pemilik IKM maka disini tim pengabdian memberikan saran \& inovasi kepada kepada pemilik IKM yaitu sistem manajemen strategi yang efektif \& efesien meliputi dari penjualan, pengembangan sumber daya manusia, Keuangan, dan proses Produksi.

Berikut adalah hasil penelitian ini dan berikut adalah visi dan misi dari industri kecil menengah Pabrik Kerupuk Sari Ikan Desa Penganjang Kecamatan Sindang Kabupaten Indramayu. Visinya yaitu memperkenalkan dan mempertahankan kualitas produk makanan Indonesia kerupuk dan mampu menjadi makanan yang berkualitas. Menarik dan diterima oleh kalangan masyarakat sebagai makanan cepat saji atau cemilan serta merambah pasar menengah keatas dan juga pasar menengah kebawah untuk memperluas pasar. Misinya yaitu menciptakan makanan dari bahan-bahan 
yang alami, ingin menghasilkan kualitas rasa yang lebih gurih, ingin mempunyai pabrik disetiap daerah.

Jam kerja pukul 06.00 dan jam keluar pukul 14.00 sehingga waktu kerjanya selama 8 jam. Berikut laporan laba rugi Pabrik Kerupuk Sari Ikan pada tabel berikut:

Tabel 1. Laporan laba rugi

Pabrik Kerupuk Sari Ikan

Pendapatana jasa

Rp. 2.400 .000

Beban - beban :

Beban Gaji

Rp. 1.800 .000

Beban Perlengkapan

Rp. 1.960 .000

Beban Penyusutan Peralatan

Rp. 2.640 .000

Total Beban

Rp. $(6.400 .000)$

Laba Bersih

Rp. 4.000 .000 
NERACA PD. SARI IKAN

Per 31 Januari 2020

\begin{tabular}{|c|c|c|c|}
\hline \multicolumn{2}{|c|}{ AKTIVA } & \multicolumn{2}{|c|}{ PASIVA } \\
\hline Aktiva Lancar & & Hutang Jangka P & adek \\
\hline Kas dan setara kas & $\begin{array}{l}\text { Rp. } \\
4.000 .000\end{array}$ & Hutang Usaha & - \\
\hline Piutang : & - & Hutang Lainnya & - \\
\hline Piutang Usaha & - & Jumlah & - \\
\hline $\begin{array}{l}\text { Piutang } \\
\text { Lainnya }\end{array}$ & - & & \\
\hline Persediaan & Rp. 1.000 .000 & & \\
\hline Jumlah & Rp. 5.000 .000 & & \\
\hline Aktiva Tetap & & $\begin{array}{l}\text { Hutang Jangka } \\
\text { Panjang }\end{array}$ & - \\
\hline Tanah dan Bangunan & Rp. 6.000 .000 & Modal Pemilik & Rp. 20.000 .000 \\
\hline Mesin & Rp. 4.000 .000 & Laba ditahan & \\
\hline Kendaraan & Rp. 9.000 .000 & $\begin{array}{l}\text { Laba tahun } \\
\text { berjalan }\end{array}$ & Rp. $\quad 4.000 .000$ \\
\hline Jumlah & Rp. 19.000.000 & $\begin{array}{l}\text { Jumlah } \\
24.000 .000\end{array}$ & $\mathrm{Rp}$. \\
\hline Total & Rp. 24.000 .000 & Total & Rp. 24.000 .000 \\
\hline
\end{tabular}

Tabel 1 di atas merupakan hasil pengabdian masyarakat yang dilakukan oleh tim. Sebelumnya pada usaha industri ini belum memiliki catatan dan akuntansi keuangan. Setelah dilakukan pelatihan pengelolaan catatan keuangan, pemilik 
usaha dapat memonitoring keuangan usahanya dan harapan dari tim pengabdian usaha industry Kerupuk Sari Ikan dapat berkembang

Aspek Sumber Daya Manusia

Menurut Sirait (2017), beliau Sumber Daya Manusia (SDM) adalah aset yang paling penting diantara asset - asset yang lainnya karena SDM merupakan penggerak utama sistem managemen perusahaan. Untuk itu SDM perlu dikembangkan, karena kemajuan teknologi sangat berkembang cepat. Hal ini dilakukan supaya perusahaan dapat bersaing dengan perusahaan yang lain (Dipang, 2013). Untuk itu diperlukan menejemen SDM yang handal sehingga SDM efektif dan efisien sesuai tujuan perusahaan (Istiantara, D. T., 2019). Menurut M.T.E. Hariandja (2002:2) berpendapat bahwa Sumber Daya Manusia adalah salah satu faktor yang paling utama pada suatu perusahaan dilihat dari faktor-faktor lainnya selain modal usaha. Oleh karenanya, SDM sangat diperlukan untuk dikelola dengan baik agar efektivitas dan efisiensi perusahaan semakin meningkat. Permasalahan sumber daya manusia dipabrik krupuk sari ikan milik Pak Iing yaitu: Job Description, Struktur organisasi, Jadwal jam kerja, Tidak ada Visi Misi perusahaan.

Aspek Keuangan

Menurut Ridwan dan Inge, keuangan merupakan ilmu dan seni dalam mengelola uang yang mempengaruhi kehidupan setiap orang dan setiap organisasi (Wulandari, I, \& Utami, E. S, 2020). Keuangan berhubungan dengan proses, lembaga, pasar, dan instrument yang terlibat dalam transfer uang diantara individu maupun antara bisnis dan pemerintah.

Menurut Sutrisno (2003) Manajemen Keuangan adalah semua kegiatan perusahaan dengan usaha-usaha untuk memperoleh dana perusahaan dengan biaya yang murah serta usaha untuk memakai dan mengalokasikan dana tersebut secara efisien.

Sedangkan menurut Sundjaja dan Barlian (2003), mengemukakan bahwa Manajemen yang berkaitan dengan tugas sebagai pengaturan keuangan dalam suatu usaha bisnis (Mamarimbing, et. al, 2016). Pengaturan keuangan yang baik akan menghasilkan laporan yang baik. (Rahmadoni, 2018). Manajemen keuangan yang baik juga mempengaruhi kinerja dari 
karyawan (Pohan, S., \& Hutabarat, I, 2018). Dengan demikian manajemen keuangan sangat diperlukan oleh semua bidang usaha

Permasalahan keuangan dipabrik kerupuk sari ikan milik pak iing yaitu: Di pabrik krupuk milik pak ling belum tersedia laporan keuangan secara lengkap, jadi kami akan membuatkan laporan keuangan dipabrik krupuk milik Pak ling.

Aspek Pemasaran

Menurut Philip Kotler \& Armstrong (2002:14) menyatakan bahwa Manajemen pemasaran adalah analisis, perencanaan, pelaksanaan, dan pengendalian atas program yang dirancang untuk menciptakan, membangun, dan mempertahankan pertukaran yang menguntungkan dengan pembeli sasaran dengan maksud untuk mencapai sasaran organisasi.

Menurut Prianggani, A, (2013) menyatakan Manajemen Pemasaran adalah kegiatan pokok yang wajib dilakukan oleh perusahaan untuk mempertahankan kelangsungan perusahaannya, untuk berkembang, dan untuk mendapatkan laba. Proses perencanaan pemasaran itu dimulai sebelum barang-barang diproduksi, dan tidak berakhir dengan penjualan.

Dalam pelaksanaan Manajemen pemasaran dibutuhkan strategi pemasaran yang tepat. Strategi pemasaran adalah pemahaman tentang konsep pemasaran dimana kepuasan pelanggan adalah titik sentralnya (Barusman, A. R. P, 2014). Pada saat ini, setiap pelaku usaha harus mampu melaukan strategi pemasaran secara online untuk mengembangkan usahanya Nurpratama, M., \& Anwar, S (2020). Permasalahan pemasaran dipabrik krupuk sari ikan pak iing yaitu: (1) Belum bisa memasarkan kerupuk sampai keluar kota indramayu dikarenakan keterbatasan modal. (2) Belum bisa memasarkan kerupuk secara online dikarenakan pak iing kurang menguasai teknologi.

\section{Aspek Produksi}

Menurut Handoko (2000:3) Manajemen Produksi adalah usaha-usaha pengelolaan secara optimal, penggunaan sumber daya-sumber daya (atau sering disebut faktor-faktor produksi), tenaga kerja, mesin-mesin, peralatan, bahan mentah dan sebagainya dalam proses transformasi bahan mentah dan 
tenaga kerja menjadi berbagai produk atau jasa. Menurut Siswati, L., Harly, R., \& Afrijon (2017), tiga faktor yang mempengaruhi manajemen Produksi adalah modal, tanah/ lahan, dan tenaga kerja. Menurut Cahyaningrum, M. C. K., \& Suamba, I. K (2018) manajemen produksi dilakukan saat perencanaan hingga pengawasan produksi, sertifikasi produk untuk menjamin kualitas, serta manajemen pemasaran untuk memperluas pasar dan saluran distribusi agar produk dapat dipasarkan dengan baik hingga sampai di tangan konsumen. Permasalahan produksi dipabrik kerupuk sari ikan milik pak iing yaitu: Pabrik kerupuk pak iing produksi kerupuknya terbatas hanya memproduksi kerupuk lembang saja tidak ada varian krupuk yang lain .

\section{Pembahasan}

Aspek Sumber daya manusia (SDM)

Membuat struktur organisasi

Pentingnya Struktur Organisasi untuk mengatur hubungan yang baik antar unit maupun intern unit itu sendiri. itu dimaksudkan agar memanfaatkan semua kemampuan ke suatu tujuan perusahaan sesuai dengan visi misi perusahaan.Selain itu akan mempermudah dalam pengintegrasian fungsi fungsi dalam perusahaan agar efektif dan efisien.

Membuat jadwal jam kerja

Dengan memberikan kebijakan jam kerja, karyawan akan merasa lebih dihargai dan diperlakukan dengan baik oleh suatu perusahaan. Selain itu, jam fleksibel secara tidak langsung juga akan mempererat hubungan antara manajer dan karyawan di perusahaan tersebut. Karyawan yang dibolehkan bekerja dengan jam fleksibel biasanya lebih puas dengan pekerjaan mereka dan jarang mengeluh. Hal itu juga berpengaruh pada peningkatan loyalitas setiap karyawan di perusahaan.

\section{Membuat Job description}

Job description merupakan bagian penting dari sistem pengembangan SDM. Job description berfungsi untuk menjelaskan tugas, tanggung jawab serta wewenang yang akan dipegang pada 
sebuah jabatan secara garis besar. Job description dapat dikatakan sebagai peta yang memberikan arah kepada organisasi, sehingga tujuan organisasi dapat tercapai.

\section{Membuat Visi Misi}

Visi dan Misi merupakan sebuah tolak ukur untuk mencapai kesuksesan dan kemajuan perusahaan, sehingga dalam praktiknya, perusahaan memiliki dasar dalam membuat kebijakan dan aturan untuk kepentingan perusahaan maupun karyawan.

Aspek Keuangan

Membuat laporan keuangan

Pembuatan laporan keuangan perusahaan merupakan hal yang wajib dilakukan oleh mereka yang bergerak dalam dunia usaha. Semua usaha yang ingin dikelola dengan baik, harus memiliki sebuah catatan yang berisi informasi mengenai semua aktivitas keuangan mereka. Bukan hanya perusahaan yang sudah berskala besar yang memiliki kewajiban untuk membuat laporan keuangan perusahaan. Sebab, perusahaan kecil sekalipun sebenarnya dianjurkan untuk membuat laporan keuangan perusahaan mereka. Karena pada dasarnya laporan keuangan yang dibuat tersebut pada nantinya akan bermanfaat untuk diri mereka sendiri.

\section{Aspek Pemasaran}

Pemasaran produk secara online (Facebook dan Instagram)

Pemasaran online sendiri adalah suatu aktifitas promosi untuk mengenalkan atau mempromosikan suatu produk maupun jasa dimana proses pemasaran tersebut dilakukan secara online melalui media internet dan juga kecanggihan teknologi. Tujuannya tentu tidak lain tidak bukan yaitu demi membuat proses marketing ini agar lebih efektif, baik dari segi waktu, tenaga maupun biaya. Pemasaran online terbukti sudah memberikan banyak manfaat bagi para pebisnis. Misalnya, membantu perusahaan untuk melakukan riset sendiri. Namun, menggabungkan antara pemasaran online dan offline adalah cara yang 
sangat baik. Akan tetapi manfaat pemasaran online tersebut bisa membantu anda para pebisnis untuk menciptakan strategi pemasaran secara tepat, bahkan dapat lebih sukses dari pemasaran offline.

Aspek produksi

Membuat inovasi krupuk nemambahkan rasa pedas dan asin, yang isinya 5 biji krupuk dengan harga 1.000 rupiah.

Mendengar kata "inovasi", pikiran orang biasanya akan tertuju pada berbagai upaya untuk menemukan hal baru, hal yang berbeda dari yang telah ada, hal yang memiliki nilai lebih, atau dalam sebuah tindakan, bagaimana melakukan terobosan, gebrakan yang berbeda yang belum pernah dilakukan sebelumnya. Dalam bentuk negatif, inovasi juga dapat diasosiasikan sebagai bentuk ketidaknyamanan berkaitan dengan sebuah perubahan tersebut. Namun, jika ditelaah lebih dalam, inovasi tidak selalu berupa temuan-temuan besar yang mengguncang dunia. Temuan-temuan yang kecil yang nampak sepele pun ternyata bisa berpengaruh besar terhadap kinerja perusahaan.

\section{Kesimpulan dan saran}

Kesimpulan

Berdasarkan kegiatan kegiatan yang telah kami lakukan, yakni dari observasi sampai dengan penulisan laporan ini, maka dapat ditarik kesimpulan sebagai berikut:

Perlu adanya pemasaran online.

Perlu mengoptimalkan cara memasarkan poduk sampai ke luar indramayu. Inovasi produk dengan menambah varian rasa.

Perlunya meningkatkan proses penjemuran.

Membuatkan struktur organisasi untuk IKM.

Membuat jadwal jam kerja.

Membuat job description.

Membuat visi misi perusahaan.

Membuat laporan keuangan. 
Saran

Sebagai bahan masukan untuk pengelola industri guna meningkatkan kualitas pelaksanaan dimasa mendatang, maka dapat kami sampaikan saran-saran sebagai berikut:

Lebih memperhatikan bagian keuangan, Sumber Daya Manusia, Pemasaran dan Produksi demi kelancaran dan kemajuan perusahaan.

Program kerja yang kami usulkan semoga bisa di pertimbangkan demi keamajuan perusahaan.

\section{Daftar Pustaka}

Amstrong, Gary \& Philip, Kotler. 2002. Dasar-dasar Pemasaran. Jilid 1, Alih. Bahasa Alexander Sindoro dan Benyamin Molan. Jakarta: Prenhallindo,

Barusman, A. R. P. 2014. Analisis Strategi Bauran Pemasaran Terhadap Kepuasan Konsumen Di Bubur Gabe Bandar Lampung. Jurnal Manajemen dan Bisnis, 4(2), $179-196$.

Cahyaningrum, M. C. K., \& Suamba, I. K. 2018. Manajemen Produksi dan Pemasaran Benih Padi di PT. PERTANI (Persero) Cabang Bali. E-Jurnal Agribisnis dan Agrowisata, 7(1), 11 - 20.

Dipang, L. 2013. Pengembangan Sumber Daya Manusia Dalam Peningkatan Kinerja Karyawan Pada PT Hasjrat Abadi Manado.Jurnal EMBA, 1(3), 10801088.

Hariandja, Marihot T. E. 2002. Manajemen Sumber Daya Manusia. Jakarta: Grasindo.

Handoko T. Hani. 2000. Manajemen Personalia dan Sumberdaya Manusia,. Edisi II, Cetakan Keempat Belas, Penerbit BPFE, Yogyakarta

Istiantara, D. T. 2019. Pengembangan Manajemen Sumber Daya Manusia Berbasis Kompetensi Guna Meningkatkan Kinerja Pegawai Dan Dosen Polikteknik Perkeretaapian Indonesia. Jurnal Perkeretaapian Indonesia, 3(2), 93 - 101.

Nurpratama, M., \& Anwar, S. 2020. Penerapan Digital Marketing Bagi Usaha Mikro, Kecil Dan Menengah (Umkm) Di Kelurahan Karangmalang Kecamatan Indramayu Kabupaten Indramayu. Investasi, 6(2), 87 - 102. 
Mamarimbing, J. M., Sepang. J. L., Mintardjo, C. M. O. .2016.Analisis Sensivitas To Market Risk Pada Perusahaan Sektor Perbankan (Bank-Bank Bumn) Periode 2011-2014. JURNAL EMBA, 4(2), 758 - 766.

Pohan, S., \& Hutabarat, I. 2018. Pengaruh Manajemen Keuangan terhadap Kinerja Aparatur Sipil Negara (ASN) pada Bagian Perekonomian dan Pembangunan Setda Kabupaten Tapanuli Tengah. JESYA, 1(1), 41 - 50.

Priangani, A. 2013. Memperkuat Manajemen Pemasaran Dalam Konteks Persaingan Global. Jurnal Kebangsaan, 4(1), 1 - 9.

Rahmadoni, J. 2018. Isu Global Manajemen Pembiayaan Pendidikan Di SD Indonesian Creative School Pekanbaru. JMKSP, 3(2), 161 - 169.

Sirait, A. I. S., Tamami, S, \& Wibowo, E. A. 2017. Pengaruh Gaya Kepemimpinan, Motivasi dan Kepuasan Kerja Terhadap Kinerja Karyawan Pada PT. Citra Shipyard Batam.Jurnal Bening, 4(2), 1 - 21.

Siswati, L., Harly, R., \& Afrijon. 2017. Manajemen Produksi Dan Pemeliharaan Kebun Kelapa Sawit Rakyat. Jurnal Agribisnis, 19(2), 95 - 101.

Sutrisno. 2003. Manajemen Keuangan Teori, Konsep dan Aplikasi. Yogyakarta: Ekonosia.

Wulandari, I, \& Utami, E. S. 2020. Perencanaan dan Pengeloalaan Keuangan Keluarga pada Ibu Rumah Tangga Dusun Pasekan Lor, Balecatur, Gamping, Sleman, Yogyakarta. JURNAL ABDIMAS BSI, 3(2), 236 - 243. 